\title{
Celebrity 2.0: \\ The Case of Marina Abramović
}

\author{
Sharon Marcus
}

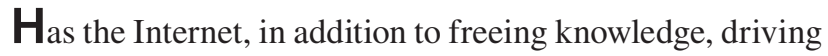
us to distraction, and allowing us to shop without leaving the house, also radically changed celebrity culture? To answer this question requires taking a long historical view that juxtaposes figures who attained celebrity in previous eras with those who have done so more recently.

\section{Celebrity Culture, Old and New}

In the decades since Leo Braudy published The Frenzy of Renown (1997 [1986]), scholars have emphasized celebrity's dependence on media. Without portrait busts and coins, without broadsides and woodcuts, without newspapers and photographs, without film and television-no celebrity. This dependence on media has often led scholars to assume that when media formats and channels undergo radical shifts, celebrity changes too. Yet many such claims for innovation wither under historical scrutiny. Film stardom only looks like a new invention if one studies it in isolation from the theatrical "star system" on which it capitalized. ${ }^{1}$ Think that Hollywood gossip columnists and television talk show hosts invented the idea of asking celebrities to expose their private lives to public scrutiny? Meet Edmund Yates, who between 1877 and 1879 published three volumes of essays titled Celebrities at Home (1877-79). Today's fan websites have their counterparts in the photo albums and scrapbooks compiled by theatergoers over a century ago (Garvey 2012), and fans have been buying tie-in merchandise and copying celebrity fashions and hairstyles for at least two centuries. Stalking, fan fiction, and the print equivalents of leaked sex videos have been around since Lord Byron's fans

1. For an early example of the phrase star system being used to describe theater, see "The True Story of Sarah-Bernhardt" (Life 1879: 6). 
sent him locks of their pubic hair and one of his angry ex-lovers published a thinly veiled account of their liaison (Tuite 2007).

Many of the changes that new media scholars attribute to platforms such as Twitter are in fact holdovers from old media. Twitter and other "spreadable media" did not invent the debate and engagement that many see as their hallmarks; celebrity culture has thrived on scandal and controversy since the eighteenth century. ${ }^{2}$ Theater, radio, film, television, sports, and pop stars performed immediacy, authenticity, and intimacy long before the advent of reality TV and Instagram — by directly addressing audiences, for example, or by sending personalized replies to fan mail (see Stacey 1994; Marcus 2011; Marshall 1997; Smart 2005; Murray 2005; Langer 2006; Polan 2011). Since at least the 1920s, celebrities have crafted personae that balance ordinariness and extraordinariness, accessibility and distance, publicity and privacy. When celebrities use social media such as Twitter, Facebook, and blogs to achieve these goals (Marwick and boyd 2011: 144), they adapt new means to old ends. Indeed, one might say that contemporary social media have succeeded by latching onto a preexisting celebrity culture in order to promote themselves - as did photography and journalism in the 1870s, film and radio in the 1910s and 1920s, TV in the 1950s, and video in the 1980s. In this sense, new media have extended and renewed preexisting versions of celebrity culture more than they have disrupted them-which helps explain why each wave of new media seems to make celebrity culture more pervasive.

Nonetheless, most people who have lived through the past several decades feel strongly that the Internet has dramatically changed celebrity culture. Given that celebrity consists in large part of public impressions, this feeling is worth taking seriously. Have new media qualitatively transformed celebrity culture or merely increased its speed and extended its reach? The explanations and criticisms of celebrity culture that scholars offered before the advent of the Internet remain as true now as they were then: its links to status systems (Mills 1999 [1956]; Kurzman et al. 2007; Milner 2010) and the manufacture of identities (Gamson 1994; Stacey 1994); its spurious promises of democracy (Marshall 1997; Turner 2004), promotion of conspicuous consumption, and preoccupation with superficial personal traits (Lowenthal 1968; Boorstin 2006; Rojek 2001); and its investment in a false sense of individuality and intimacy (Adorno 2001; Debord 1977; Schickel 1985) and in capitalist ideologies of individualism and commodification (Morin

2. On the roots of scandal in the eighteenth century, see Nussbaum 2010. For accounts that highlight the participatory nature of Internet fandom, see Jenkins, Ford, and Green 2013 and Hirschorn 2013. 

anic promises to the contrary, the Internet has not eliminated ideology, commodification, or status hierarchies. It may be easier, then, to see how the Internet has changed celebrity culture if, instead of focusing on what celebrity culture does, we focus on how it works.

First, some definitions. I use the term celebrity culture to refer to the individual celebrities, publics, journalists, publicists, institutions, and industries that produce and consume celebrity and celebrity discourse to refer to the media objects that those entities produce, consume, and distribute. At the heart of celebrity culture is the celebrity: a person whose name, face, or voice commands recognition among more people than he or she can possibly know and, more importantly, among more people than can possibly know one another. Celebrities, then, are not only known beyond their own social networks (Milner 2010: 387); they are also known beyond their fans' social networks - and not only by fans. Celebrities thus become public hubs, linking even people who do not seek out information about them. You may actively avoid sports, but you probably know which one David Beckham plays. You may not know what Justin Bieber's or Taylor Swift's music sounds like, but chances are you have heard of them. If you have bought milk or toilet paper in the past ten years, you have seen the Kardashians on the covers of magazines and are likely to recognize their faces, even if you cannot tell Kim from Khloe and have never heard of, let alone watched, the television shows that made them famous.

Celebrities by definition attract the attention of yery large numbers of people, who, far from constituting a homogeneous mass, fall into at least three different groups: fans and what I call the voluntary and involuntary publics. Fans devote time and energy to learning about celebrities through multiple channels, often demonstrating interest in their personal qualities and private lives, sometimes even seeking contact with other fans and with celebrities themselves. You are a fan if you follow Rihanna on Twitter, read about her in Us Weekly or Gawker, set up a Google alert for her name, or avail yourself of opportunities to see her in person. Many people have fans; only if those fans are so numerous that they could not all know one another are those people celebrities. The voluntary public also chooses to engage with the celebrity, but through a minimal number of media channels and in the least expensive, least personalized, and least effortful ways. You join an athlete's voluntary public if you watch him or her play in a televised game; you join a musician's voluntary public if you choose to listen to his or her recorded music. Rihanna is a celebrity because, unlike many musicians, the number of people who actively seek out her music is so large that her listeners' 
social networks could not all overlap. The involuntary public is exposed to celebrity imagery and information without seeking it out. You belong to Rihanna's involuntary public if you have heard her songs playing on the radio, seen her ads for coconut water, read friends' posts about her on Facebook, or Googled her to figure out who this "Rihanna" is that you hear mentioned everywhere. One definition of superstars - Rihanna, Beyoncé, Jay-Z, Miley Cyrus - is that they have an involuntary public, and one reason that so many people experience celebrity culture as hijacking public discourse is that it successfully insinuates itself into the consciousness of even those indifferent or hostile to it.

\section{The Case of Marina Abramović}

Depending on whom you ask, the artist Marina Abramović is a diva in the tradition of Sarah Bernhardt and Maria Callas, a brilliant self-promoter whose all-toosuccessful pursuit of celebrity has compromised her artistic integrity, an art world veteran with only a coterie following, or a nonentity-Marina who? - whose name is as unrecognizable as it is unpronounceable. On the one hand, these responses reflect the fact that Abramović's celebrity is minor compared to that of Beyoncé, Kobe Bryant, or Cyrus: her involuntary public is small, and many people have not heard of her and would not recognize her image. On the other hand, these responses capture how Abramović's celebrity has recently grown, with her fans and voluntary public now numbering in the hundreds of thousands. In the past three years, Abramovic has appeared on the cover of Serbian Elle, been the subject of a theatrically released HBO documentary, made a video with Lady Gaga that was viewed over 4 million times in seven months (MAI 2013a), and been featured in a front-page Sunday New York Times article that described her as a "celebrity darling" (Lyall 2013). Abramović embraces her newfound stardom; asked by Dust Magazine how she felt about having become "a famous media persona, a glamorous icon," Abramović (2013: 000) replied, "Why should I return to be an unknown artist again?" (n.p.). To be sure, Abramović ceased to be an unknown artist several decades ago. Born in 1946, she has been internationally active since the 1970s, and her reputation grew steadily from the late 1990s onward. Nonetheless, as late as 2004, performance studies scholar Peggy Phelan (2004: 569) could accurately describe even the increased levels of attention that Abramović was receiving as "not quite celebrity."

The event that definitively transformed Abramović into a celebrity was "The Artist Is Present," a 716-hour and 30-minute live performance in spring 2010 that also gave its name to the one-woman retrospective that the Museum of Modern 
Art (MoMA) simultaneously devoted to her work, an exhibition that drew over 850,000 visitors, breaking museum attendance records. Abramović's live performance had a relatively simple structure. In the museum's second-floor atrium, within a rectangle demarcated by tape, illuminated by bright theatrical lights at each corner, Abramović sat in a chair each day that the museum was open from March 14 through May 31 and invited visitors to sit opposite her, in silence, one by one, for as long as they desired, while she maintained eye contact with them (see figs. 1 and 2). On the last day, Abramović ended the performance by dramatically slipping to the floor and then standing to receive a fifteen-minute ovation from a crowd more than ten persons deep (Yablonsky 2010), whose size attested to how much of an event her piece had become (see fig. 3). Over the course of the exhibit,

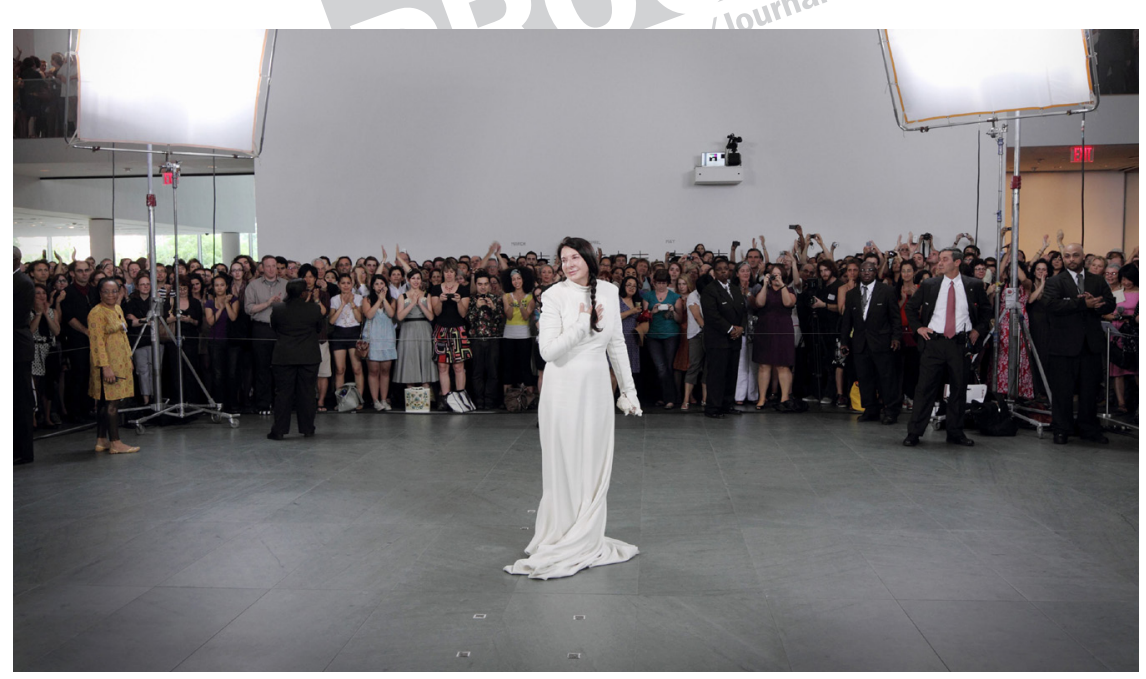

Figures 1 and 2 Marina Abramović, "The Artist Is Present." Performance, three months, the Museum of Modern Art, New York, 2010. Photography by Marco Anelli. Courtesy Marina Abramović Archives

Figure 3 Marina Abramović, "The Artist is Present." Performance, three months, the Museum of Modern Art, New York, 2010. Photograph by Marco Anelli. Courtesy Marina Abramović Archives 
Public Culture

Figure 4 Photograph by Marco Anelli @ 2010. Courtesy Danziger Gallery. From Portraits in the Presence of Marina Abramović (Anelli 2012)
Abramović faced 1,545 visitors, including some celebrities (Lou Reed, Patti Smith, Rufus Wainwright, Isabella Rossellini, and Björk) and many lesser-known performance artists. Some participants sat opposite Abramović for many hours and attempted to speak to her or give her gifts; on the last day, a visitor vomited from the sidelines and a sitter removed her clothes, only to be quickly removed by security guards (Chen 2010). Most, however, sat for five minutes or less and followed the rules forbidding sitters from touching or speaking to the artist.

Within days of the show opening, visitors were accumulating in the atrium, watching from the sidelines or enduring long lines for the chance to take a seat opposite the artist. On many mornings, a crowd of would-be sitters would gather early on the museum's ground floor and be held back by security guards, then race up the stairs to the second-floor atrium to secure the best possible place in line (see fig. 4). By the time the show closed, Abramović was "inspiring a devotion that border[ed] on the obsessive from her legions of fans" (O'Hagan 2010), with hundreds of people queuing outside the museum overnight and the artist herself garnering "as much mainstream press as a pop star" (Yablonsky 2010). Celebrity site

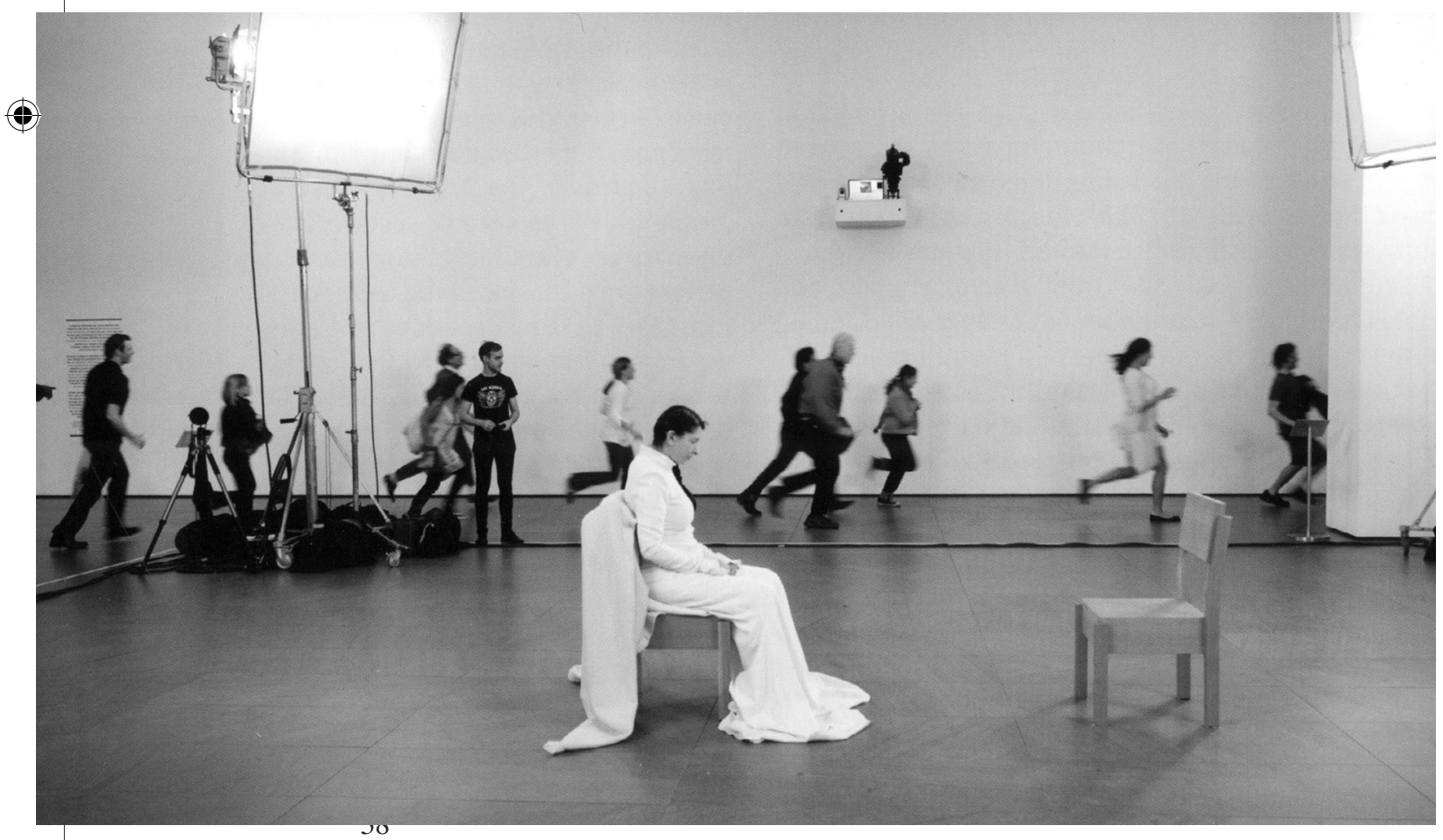


1 Gawker.com called the show "easily

2 the most buzzed-about performance

3 art piece since James Franco went 4 on General Hospital" (Chen 2010).

As Abigail Levine (2010) has noted, "The Artist Is Present" sparked debates about whether it was an ascetic, meditative ritual, "unabashed celebrity worship," or a refusal of the dichotomy between artistic merit and popular success. ${ }^{3}$ Subsequent events have affirmed the show's iconic status and increased Abramović's links to celebrity culture. In July 2013, for example, rap superstar Jay-Z invited Abramović to participate in a gallery performance that he explicitly modeled on "The Artist Is Present," titled "Picasso Baby." Over the course of several hours, filmed by HBO, Jay- $Z$ rapped the show's title song repeatedly while dancing with individual gallery visitors, including Abramović herself (see fig. 5). The artist's ability to hold her own with the charismatic rapper-mounting a bench to loom over him with arms outspread, touching her forehead to his, and holding his gaze-moved even the avowedly skeptical art critic Jerry Saltz (2013) to describe her presence as "astonishing." Jay-Z's decision to rap live in an art gallery while singing about his desire to own expensive art resonated with how "The Artist Is Present" had itself combined esoteric performance art with the outsize success of celebrity. Abramović's willingness to appear with Jay-Z only increased her name and face recognition by familiarizing millions of the rap star's fans with her work. As a woman put it

Figure 5 Jay-Z and Marina Abramović at Pace Gallery, New York, July 10, 2013. Courtesy Fairchild Photo Service 
Public Culture when commenting in July 2013 on a 2010 MoMA video about Abramović, "Forehead to forehead with Jay-Z brought me here." 4

Because we can locate Abramović's transition to celebrity so precisely, she offers a signal case study for analyzing the Internet's impact on celebrity culture. Her 2010 MoMA performance was heavily promoted through Internet platforms that were themselves experiencing a significant surge in popularity at that very moment. MoMA advertised the show using traditional methods, such as giant billboards in SoHo and on the Lower East Side (see fig. 6), but it also initiated a web publicity campaign so successful that art blogger Hrag Vartanian (2010)

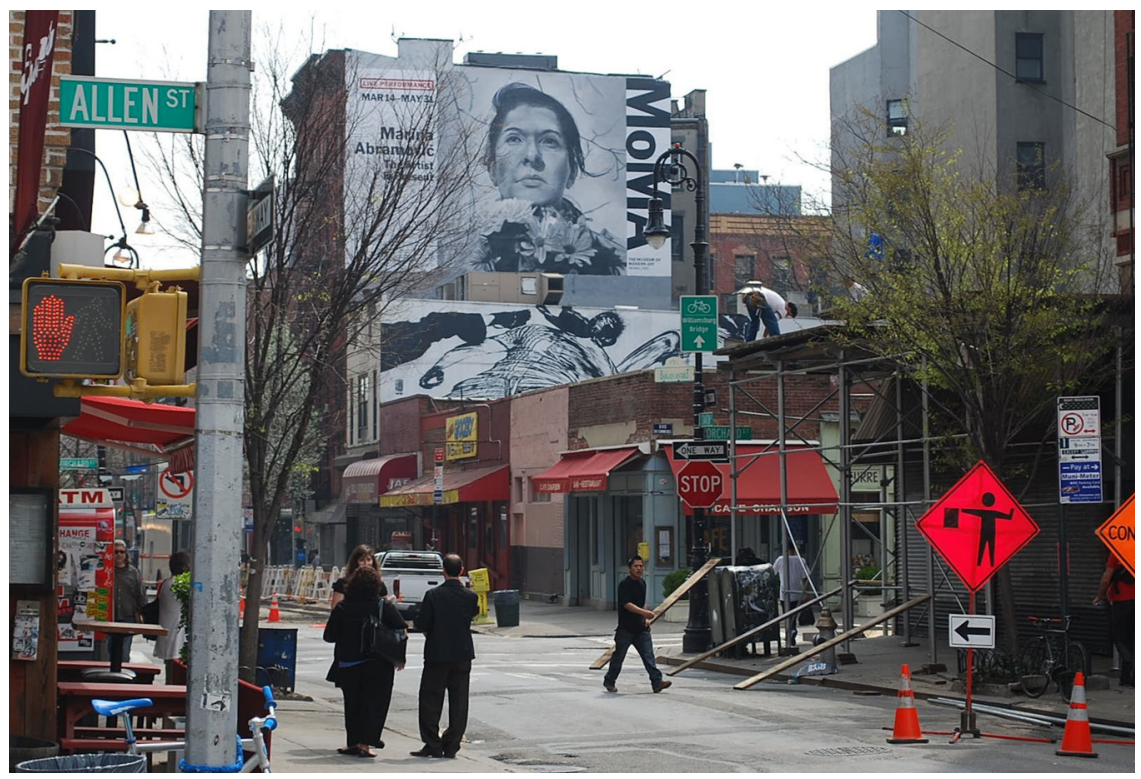

Figure 6 MoMA Lower East Side billboard for “The Artist Is Present." Photograph by Alison Young

commented: "Everyone at MoMA and their social media mavens need to be given a raise. ... . The crew at MoMA has this social media thing totally under control and I suspect everyone will look to them from now on to set the pace." In fact, the museum's campaign was so successful precisely because it quickly exceeded MoMA's control, yielding high levels of user-driven posting about the performance through Twitter, Tumblr, YouTube, Vimeo, Facebook, and Flickr and on personal blogs (Vartanian 2010; Fisher 2012). "The Artist Is Present" was also

4. The video was "Marina Abramovic: Live at MoMA" (MoMA 2010). 

daily updated a Flickr site that featured individual photographs of each person who sat opposite her. The publicity attending the event did not make explicit whether Abramović took an active role in those measures or merely approved them, but since 2010 she has herself become an adept user of social media, maintaining an active Twitter feed and Facebook page and raising over $\$ 600,000$ via Kickstarter to found the Marina Abramović Institute (MAI), devoted to teaching her durational performance methods. The Kickstarter site promises that "Marina will personally thank all those who contribute to the creation of MAI by hugging every backer ... a at a live event called THE EMBRACE" (MAI 2013b), which suggests that Abramović sees the structure of "The Artist Is Present"-the artist's live interaction with multiple audience members on an individual basis - as key to her past and future success.

\section{Four Theses on Celebrity}

To what extent did Abramovićs performance and the Internet media on which its success depended represent major changes to celebrity culture, and to what extent did they simply reproduce some of its oldest characteristics? To answer this question, I offer four theses on celebrity, trace how the basis for each has changed or stayed relatively constant over time, and situate Abramović's celebrity performance in this longer history.

Thesis 1: Celebrity combines presence and representation. The Internet constitutes only the most recent phase in celebrity culture's long history of mingling the virtual and the actual. The first modern celebrities in Europe and the United States were actors, dancers, singers, politicians, and military heroes-the likes of Edward Kean, Fanny Elssler, Jenny Lind, Andrew Jackson, and the Duke of Wellington-who regularly made live appearances and were also the subjects of widely circulating biographies, newspaper articles, and printed images. Celebrity representations trigger a longing for presence that helps account for the excitement that people have long felt about seeing celebrities in person (Dames 2001) and for their fantasies about intimate contact with stars (Ferris 2011). Heavily dependent on representation, celebrity distinguishes itself from pure fiction by referring to a real presence. The more stylized and/or reclusive a celebrity, the more fans crave a view of the celebrity's authentic, backstage self, no matter now obviously manufactured. Offering the public managed glimpses of celebrities' private lives lends substance to celebrity presence and shores up belief in a celebrity's existence as a real person whose story unfolds continuously and unpredictably. 
The commercialization of photography in the 1860s, along with improvements to road, steamship, and railway travel, further knit celebrity presence to celebrity representations. Greater ease of travel led to the frequent international tours that enabled audiences in Europe, the Americas, and Australia to see performers, politicians, and authors in person, while technological advances made it increasingly cheaper for fans to buy the postcards, books, photographs, and posters that advertised and memorialized celebrity sightings in theaters and lecture halls. With the rise of film in the twentieth century, representation began to prevail over presence, and access to the star's person became the exception rather than the rule. This had the effect of making celebrities' live appearances matter even more; Su Holmes and Sean Redmond (2006: 5-6) argue that the rise of virtuality in the late twentieth century led to an increased fascination with celebrities' corporeality. Fans continue to value celebrity presence so highly that they will endure great expense and inconvenience for a chance to glimpse stars live, even in an era when one can watch their recorded performances on demand and often for free.

Celebrity presence is always shadowed by representation, and every representation of a celebrity is haunted by the desire to grasp the star in the flesh. The title and structure of "The Artist Is Present" appealed to the public desire to see stars in person by offering to reverse the priority that celerity representation has taken over celebrity presence since the advent of film. The language surrounding the show referred to "presence" in the radical sense that performance theorists use the term. As Abramović (2010a) herself put it in an interview, "The piece 'Artist Is Present' . . . is about being in the present time." Essays in the exhibition catalog linked presence to the physical concreteness and bodily challenges of durational performance, as well as to the connection and energy flow between live performers and live audiences copresent with one another (e.g., Danto 2010: 34; Fisher 2012); many who sat opposite Abramović attested to the power of being in her presence (see O'Hagan 2010). Phelan (2004) has influentially argued that performance and representation are antithetical because spectators watching a recorded video or live streaming of a remote event cannot alter what they see; unlike live performers, representations are temporally and spatially removed from audiences and are therefore indifferent and impervious to them. In the most basic sense, Abramović performed presence because visitors, rather than sit opposite a photograph of her or across from a computer screen transmitting her via Skype or webcam, sat across from her in person.

As many critics pointed out, however, "The Artist Is Present" was not an instance of pure presence (Jones 2011). Instead, it blended presence and representation, thus bringing it closer to celebrity culture. Abramović supplemented 
her live performance with representations (the webcam, the Flickr site), and even her bodily presence during the performance had affinities with representation. Draped in a distinctive monochromatic costume (blue, red, or white, depending on the month), Abramović stood out in the visual field with a clarity that recalled the graphic design of art nouveau posters, an earlier instance of cooperation between avant-garde art and cutting-edge publicity tactics (see fig. 7). The artist was present but presented herself as an iconic representation (Fisher 2012), easy to grasp, recall, and reproduce because she maintained the same basic shape across multiple iterations (Kemp 2012: 184-85, 340, 350). Abramović's refusal to speak with or react to sitters made the qualities that Phelan (1993) associates with representation-indifference and imperviousness - central to her live performance. Her stillness made her liveness all the more fascinating, and viewers fixated on the movements she made between sitters-closing her eyes, slowly rolling her shoulders, and then opening her eyes again to take in the new person opposite her. Those rare gestures created an interstitial, backstage moment that lent the show pathos and suspense by hinting at the physical pain Abramović suffered from sitting for so many hours; they also transformed the instant when the artist once again stilled her body and opened her eyes into a theatrical entrance (see the video attached to Abramović 2010a). Christopher Grobe (2011: 109, 110), noting Abramović's almost corpse-like stare,

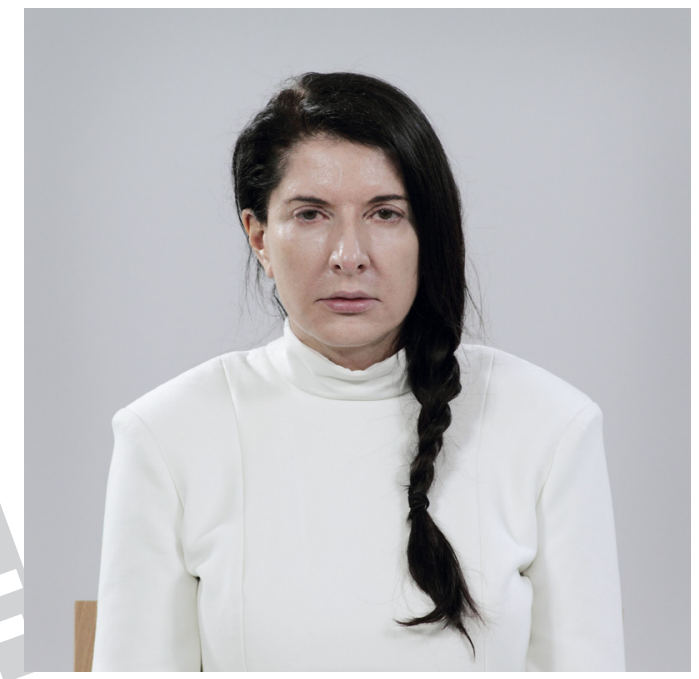

Figure 7 Marina Abramović, "The Artist Is Present." Performance, three months, the Museum of Modern Art, New York, 2010. Photography by Marco Anelli. Courtesy Marina Abramović Archives attributed the charisma of her performance to its "uncanny mixture of presence and incipient mediation." 5 Here, as in many earlier instances of celebrity, the combination of presence and representation, rather than one or the other, constituted the celebrity's allure.

Thesis 2: Celebrity culture favors resonant paradox over logical consistency. Most celebrities are bundles of contradictions (Dyer 1979: 69; Roach 2007: 8) and often combine opposed traits. Marilyn Monroe blended sexual knowingness and babyish innocence (Dyer 1979). Michael Jackson presented himself as

5. For an example of a critic who found the performance completely representational, see Jones 2011. For a critic and artist who arrived skeptical but ended up experiencing a real sense of presence, see Schor 2010. 
adult and child, male and female, black and white, human and machine (Hinerman 2006; Hamera 2012). The contradictory personae of celebrities in turn often elicit contradictory stances from publics, whose feelings about celebrities veer between attraction and repulsion, contempt and envy, derision and admiration, and identification and disidentification (Turner 2004: 55, 63; Schmid 2006; Punathambekar 2008: 289; Stacey 1994).

Here again, wittingly or not, "The Artist Is Present" positioned Abramović as a celebrity. The artist inspired resonantly contradictory reactions that ran the gamut from gushing adoration to vituperative denunciation; while waiting in line, I overheard a New York performance artist confide at length to a European gallerist about how the show's success made her feel admiration, envy, and inadequacy, leading her to question why she had never had the success that her own presence was helping to create for Abramović. Commentators also produced resonantly contradictory accounts of the artist's stance within the performance itself. To some, she appeared to be a "queenly" figure on a throne (Fisher 2012; Saltz 2010), protected by guards and receiving supplicants willing to sacrifice time and comfort for a chance to sit across from her. Others described her position as vulnerable and even lowly, resembling that of a prostitute obligated to entertain anyone who wanted contact with her and had paid MoMA's admissions fee. ${ }^{6}$ Speculations about whether the artist had so much bodily control that she could go for hours without peeing or was in fact wearing an adult diaper underneath her priestly robes illustrated well how the show rendered Abramović both noble and abject (Siegel 2010).

Thesis 3: The celebrity persona develops in relation to multiple polarities, each with a positive and negative pole. The more polarities a figure activates, the greater his or her celebrity. These polarities include attraction/repulsion, conformity/ defiance, merit/worthlessness, and originality/replicability.

Attraction/repulsion: Some celebrities elicit mostly attraction, a few thrive on repelling their publics, but the majority of celebrities veer from one pole to the other over the course of their careers or trigger both responses in equal measure, in keeping with thesis 2 , that celebrities are resonant contradictions. In her youth, nineteenth-century actress Sarah Bernhardt's unfashionably thin body invited ridicule; in middle age, commentators found her more attractive. When she continued to perform even after having a leg amputated below the knee at

6. Mira Schor (2010) captured both responses by pointing to the similarities between Abramovićs posture and costume and those of an imprisoned Marie Antoinette in a 1793 Jacques-Louis David sketch. 
age sixty, Bernhardt became an attraction in the sense popularized by showmen such as P. T. Barnum. In the twentieth century, trajectory, from the appealing cuteness of his child-star years to the less congenial weirdness of his late prime, while eliciting equal measures of adoration and revulsion at the height of his fame.

Although female celebrities usually shift from being erotic attractions in their youth to campy grotesques in old age (think of Joan Crawford or Mae West), Abramović offers the interesting case of a female star moving in the opposite direction. In the first two decades of her career, she incorporated nudity and violence into her performances in ways that framed her as an attraction but complicated her erotic appeal. An early 1975 video, for example, depicted her reciting "Art must be beautiful, artist must be beautiful," while violently brushing her hair until her scalp bled. In her 1977 piece "Imponderabilia," she and her collaborator, Ulay, stood naked in a narrow museum doorway as visitors decided which one of them to face when squeezing past (see fig. 8). In recent decades, the artist has cultivated a more conventionally attractive image, but her body, the celebrity's most powerful source of both attraction and repulsion, remains at the center of her work.

Conformity/Defiance: Some celebrities develop a persona that encompasses conformity and defiance. The John Wayne type, for example, conforms to codes of masculinity while defying strictly legal ones. Defiance of social norms characterized Lord Byron and Oscar Wilde, Katharine Hepburn, James Dean, Muhammad Ali, the Beatles, and Madonna. Conversely, there have always been celebrities, such as Queen Victoria, Loretta Young, and Bill Cosby, whose personae emphasize a normalcy, an ordinariness, and even an exemplarity that their private lives often belie. Other celebrities split the poles of defiance and conformity over the course of their celebrity careers. Michael Jackson, for

Figure 8 Marina Abramović and Ulay, "Imponderabilia." Performance, ninety minutes. Galleria Communale d'Arte Moderna, Bologna, 1977. ( Mario Carbone. Courtesy Marina Abramović Archives 
example, modeled good behavior and a fierce work ethic as a child; as an adult, his almost willful association with pedophilia flaunted his defiance of social norms.

The advent of the Internet does not appear to have significantly changed this polarity, nor did Abramović activate it in radically new ways. By her own account, Abramović pursues "art that disturbs and pushes that moment of danger" (quoted in Danto 2010: 29). In her most notorious early piece, the 1974 "Rhythm 0," for example, a nude Abramović deliberately remained passive while an audience in Naples decided how to use seventy-two objects that included a bullet, a scalpel, and a box of razor blades, along with cake, a feather, and a bandage. Though more subdued than her earlier work, "The Artist Is Present" defied physical and psychological limits and confounded the basic social norm of avoiding prolonged eye contact with strangers, linking it to her career-long interest in testing the "boundaries that define ... admissible conduct" (ibid.).

Merit/Worthlessness: Celebrity has long been rife with the vocabulary of merit. Stars attribute their success to hard work, and publics correlate celebrity to awards and other rankings of talent, earnings, and achievements. Celebrity has equally strong associations with worthlessness, however; hence those opposed to Barack Obama's 2008 candidacy could dismiss him by using "celebrity" as an epithet. Commentators seem most at ease dismissing celebrities as worthless when they or their fans belong to groups with relatively low social prestige. Figures with largely young female followings, such as Paris Hilton, Kim Kardashian, and Bieber, come to exemplify celebrity culture as hollow, inauthentic, and a waste of time. Conversely, celebrities designated as deserving by terms such as "the best," "the greatest," "champion," and "genius" are mostly men, although a few women, such as Meryl Streep, are exceptions to this rule.

Abramović has occupied the merit pole not only by linking her work to art but also by emphasizing that she undertakes strenuous athletic feats that most people could not perform. In "Balkan Baroque," in 1997, for example, she scrubbed six thousand pounds of bloody cow bones for six hours a day over four days (Biesenbach 2010b: 16). In interviews about "The Artist Is Present," Abramović (2011) emphasized its bodily and mental demands: "For two years I trained for this piece, like NASA trains astronauts. You can be trained physically, just like for the Olympics, but if you don't have the determination or willpower you can't do it." 7 To highlight the fact that she was engaging in a distinctive feat of endurance, a set of marks on the atrium wall behind her showed how many days she

7. See also the artist's comments in her interview with Rachel Dodes (Abramović 2010a). 
Figure 9 Photograph by Marco Anelli @ 2010. Courtesy Danziger Gallery. From Portraits in the Presence of Marina Abramović (Anelli 2012)

had already sat and how many remained (see fig. 9). Art critics liberally referred to Abramović's "heroism" (Biesenbach 2010a: 23; Yablonsky 2010) and cited statistics about number of visitors and hours sat to make their attributions of merit sound more objective. At the same time, the show's very success attracted a raft of negative comments that construed Abramović's newfound popularity as undeserved or even a sign of artistic failure. The ensuing debate only increased her celebrity.

Originality/Replicability: Celebrities who achieve an aura of uniqueness become, by their very distinctiveness, all the more easy to imitate; at the same time, even stars hailed for their originality advertise their debts to previous performers (Roach 2007: 8). In this respect as in others, different celebrity poles reinforce one another: claims to originality might derive from stances of defiance and lead to attributions of merit that in turn inspire imitation. In the 1870s, Bernhardt's eccentric publicity stunts, such as having herself photographed sleeping in a coffin, attracted and repelled the public in equal measure, which contributed to its perception of her as a genius with a thoroughly original personality, who could then become an easily caricatured type who spawned many imitators, including 
the actresses Olga Nethersole, Mrs. Leslie Carter, and Theda Bara. This dynamic of originality and replication has remained a feature of celebrity culture despite changes in the media landscape. Madonna's 1990s music videos cited the blonde bombshells of past eras and made her an icon imitated by young women across the world in the following decades and more recently by figures such as Lady Gaga.

A celebrity, then, is someone whose aura of originality is intensified by copying and being copied. Abramović for much of her career engaged in acts few could or would replicate. In "The Lips of Thomas," in 1975, for example, she drank a liter of wine, cut a five-pointed star in her stomach, and lay down on a cross made of ice blocks. By contrast, "The Artist Is Present" made it relatively easy for Abramović's voluntary public and fans to imitate her, since it required only that they wait in line and then engage in the relatively simple acts of sitting and staring. The mirrorlike structure of "The Artist Is Present," iterated daily, asked sitters to copy the artist and one another. Several sitters even appeared in a uniform imitating the one Abramović wore throughout the exhibit (see fig. 10). Challenging performance art's antimimetic tendencies, "The Artist Is Present" embraced the dynamic of originality and imitation central to celebrity culture.

Thesis 4: The relationship between celebrities and publics is both interdependent and asymmetrical. There are no celebrities without publics, and no fans without celebrities, hence their interdependence. Stars emit signals that acquire force only when fans receive and amplify them. But because celebrity depends on the numerical disparity between stars and publics, that interdependence is asymmetrical. Celebrities receive more attention than they can possibly repay and make money by getting fans to spend theirs. Celebrities are singular, with names and faces; publics have traditionally been collective and somewhat anonymous. Celebrity status generates an "interactional privilege" that spurs ordinary people to seek out celebrities, who in turn preserve that privilege's rarity value by limiting access to their persons (Kurzman et al. 2007; 355-57; Milner 2010: 383-84; Ferris 2011). There is an inherent conflict, however, between the need to restrict contact with fans and the need to indulge it in order to maintain one's star status.

Since at least the eighteenth century, the rise of virtuoso performers with a "distinctive affecting presence" and "a heightened sense of self-expression" (Palmer 1998: 345) has led fans to believe that proximity to a celebrity will transform them and has inspired yearnings to know a beloved performer's true self and to have their love reciprocated (Cavicchi 2011: 105). Celebrity culture has fed those desires by providing the public with scripted, controlled opportunities for 


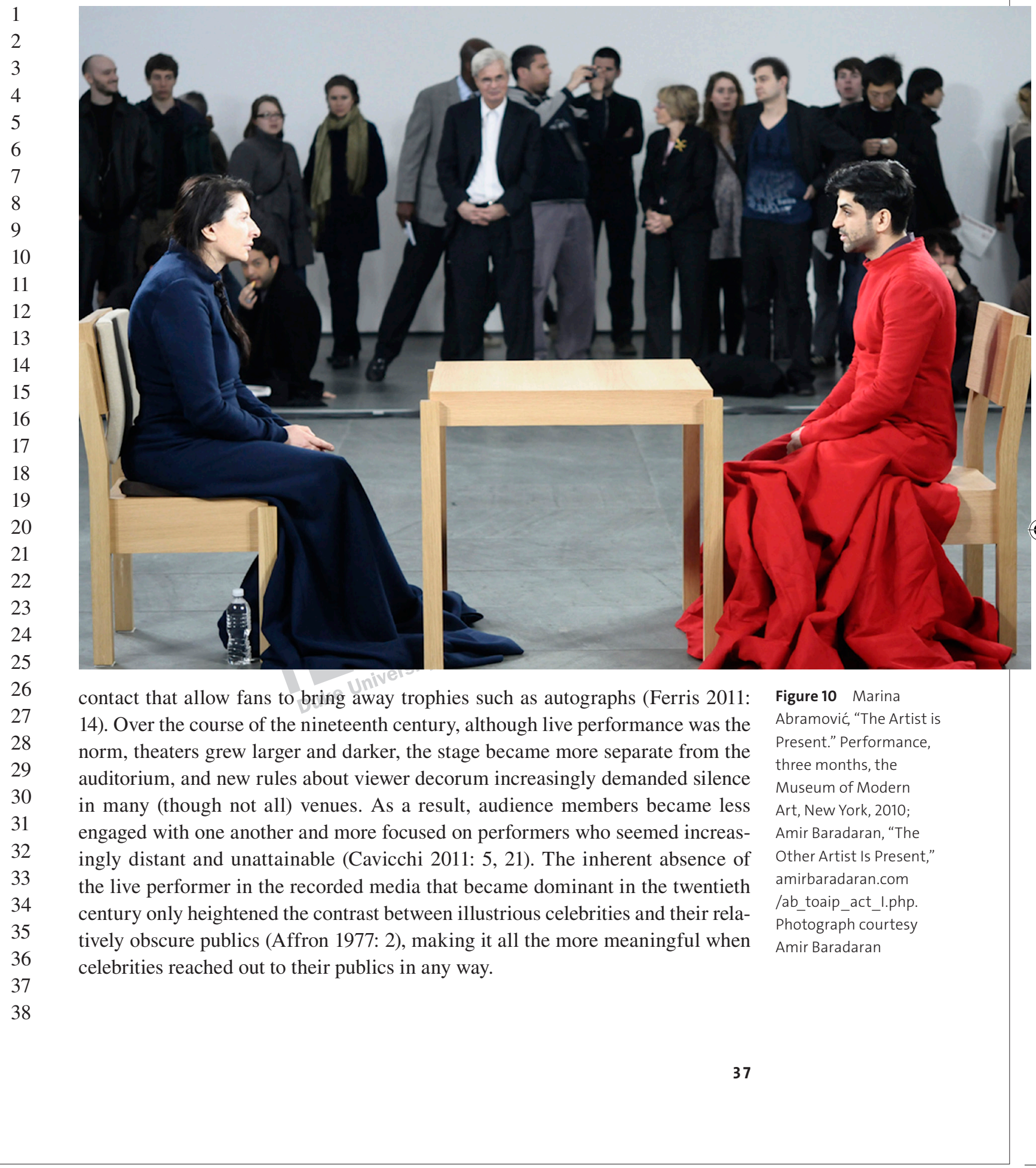


Social networking services and shows like "The Artist Is Present" appeal to the fan's desire to be seen by the celebrity. As one assiduous tweeter put it on Rihanna’s feed, “@rihanna do you see me?” (September 20, 2013, 5:05 p.m.). To a great extent, however, platforms such as Twitter and Facebook have simply expanded and sped up fan activities that have existed since the penny post and cheaper paper made it less expensive for people to send letters. Fans have sought to be seen in the company of celebrities for over a century. In the 1860s women sent actor Edwin Booth love letters and haunted the Boston pharmacy where he bought toothpaste; in 1850 Ossian Dodge circulated a counterfeit image of himself meeting the world-famous singer Lind in order to draw attention to a magazine that he edited (Cavicchi 2011: 17). Picturing himself in the presence of a celebrity enabled Dodge to increase his own fame, not only by capitalizing on Lind's but also by representing a desire so common that it has become the very motor of social media platforms: to seek attention from celebrities in order to reach both them and their publics.

\section{Performing Celebrity 2.0}

The asymmetrical interdependence between celebrities and fans represents one arena where the Internet has not only sped up and extended celebrity culture but also significantly altered it. Most interactions between fans and celebrities used to take place privately (an individual fan would write to a celebrity and receive a personal reply through the mail) or in view of a relatively small public (a local fan club, the crowd gathered outside a stage door or hotel, or the circumscribed audience captured in a taped performance). With the rise of platforms such as Facebook and Twitter, celebrity now consists to a much greater degree of interactions in which a fan addresses a celebrity in full view of the celebrity's entire Internet public, which sometimes numbers in the tens of millions. Social media connect fans to one another on an unprecedented scale, making them more visible than they have been in the past. Social media also individualize the mass of fans in the most public of ways. In both respects, social media allow fans to look and feel more like celebrities, who are defined as highly visible individuals, while still maintaining the basic gaps in status and renown that differentiate celebrities from their publics. By simultaneously bringing fans and publics closer and keeping them apart, social media appeal to fans' desires to approach celebrities in both senses of the word: to get closer to them and to become more like them.

Abramović's "The Artist Is Present" brought into focus both long-standing 

and the ways that social media have changed that asymmetrical interdependence. The performance's structure highlighted the celebrity's dependence on her public, since the show existed only because it attracted interest; had few people chosen to sit opposite the artist, there would have been no performance. At the same time, the more successful the show became, the more its structure highlighted the asymmetry between the singular celebrity and her numerous fans. In the last weeks of the show, aspiring sitters were sleeping on the sidewalk overnight to secure a place at the head of the line. Even before that, the show positioned participants as groupies, since to join its voluntary public required waiting in line as one of thousands drawn by the possibility of interacting with a celebrity in person. Over time, the line became its own locus of drama, capturing the attention of photographers, journalists, and viewers on the atrium's outer edges; I witnessed a fight almost break out between a man and a woman who had pushed ahead of him. Because visitors could sit with Abramović as long as they chose, there was constant suspense about whether even those at the very head of the line would have an opportunity to take up the prized spot. While those in line had incentive to cooperate with one another (Fisher 2012), they were nonetheless all visibly competing for a chance to be closer to Abramović, and the length of time any one visitor sat with the artist lessened the chances of those behind them. At the same time, those waiting in line often struck up conversations (ibid.) that continued online, in blogs and over e-mail (Kaganskiy 2010), making the exhibit a focal point for social interactions that displayed museum visitors simultaneously acting like fans and resisting the abjection that tinges fandom.

The disparity between celebrity and fan did not evaporate for those who achieved the distinction of sitting opposite the artist. Like all celebrities, Abramović balanced access and inaccessibility, egalitarianism and inequality, intimacy and aloofness. Although she often shed tears when those sitting opposite her cried (see Anelli 2012), her refusal to speak with sitters and her resolutely impassive facial expression injected a notable degree of distance into the intimacy of her sustained eye contact with visitors. That combination of attention and indifference, conferred in the full view of a larger public, struck many commentators as only stoking the desire to gain her recognition (Stern 2010). Only once did Abramovic touch a sitter, when she reached out to take the hands of her former lover and erstwhile collaborator Ulay, who sat with her early in the show. That exceptional moment has been viewed over thirty-eight thousand times on YouTube (e.g., restoredfaithih 2013), suggesting that it appeals to fans' wishes to see

38 
the artist acknowledge and distinguish a sitter with special attention, a wish to which Abramović already catered by engaging her audience individually, rather than as a collective.

Though Abramović never physically touched any other sitter, the moment with Ulay was not purely exceptional, since intense engagement with each individual sitter distinguished "The Artist Is Present" from Abramović's past performances. A notice prominently posted in the atrium stated that "visitors are invited to sit silently with the artist, one at a time." The performance thus individualized sitters, in a very public way; each person who sat with Abramović did so in full view of the many people waiting in line or observing the show (see figs. 1 and 2). Abramović (2010) referred explicitly to this aspect of the performance in a MoMA blog comment on the show:

What is very new about this performance is that we always perceive the audience as a group, but a group consists of many individuals. In this piece I deal with individuals of that group and it's just a one-to-one relationship. So, when you enter the square of light and you sit on that chair, you're an individual, and as an individual you are kind of isolated. And you're in a very interesting situation because you're observed by the group (the people waiting to sit), you're observed by me, and you're observing me-so it's like triple observation.

In contrast to Abramović's earlier performances, which required collective viewing or participation, "The Artist Is Present" atomized audience members at the moment they became participants and required that each sitter experience a distinct and distinguishing moment of intimacy with the artist - a moment witnessed by a crowd of other spectators, many waiting for a chance to achieve the same individual distinction of publicly visible reciprocity with the show's star.

Those moments of distinction were also witnessed by the show's even larger virtual audience, particularly via MoMA's Flickr site, which gave fans the star treatment by daily posting a high-quality color close-up of each sitter's face. Many commentators speculated that the chance to have one's photograph posted on the site and displayed to MoMA's enormous public and the Internet's potentially limitless one stoked interest in the show (Fisher 2012). To succeed in sitting opposite the artist was to acquire an interactional privilege that conferred its own fractional share of celebrity. The posting of individual photographs on the Flickr site, which had over 1.5 million visitors as of April 2014, was crucial to making "The Artist Is Present" one of the first major Internet successes of the art world. Like a Twitter feed brought to life, Abramović's show paraded the 1,545 people 
who sat with her before the public, transmitting their actions in real time and archiving them for posterity; "once documented, all images were slated to enter into Abramović's oeuvre and MoMA's collection" (ibid.: 157), and sitters who sat with Abramović multiple times themselves became the subject of blog entries and news articles. Makeup artist Paco Blancas, who sat with Abramović a total of twenty-one times, earned the "reverence" of fellow visitors (Kaganskiy 2010) and acquired a "mini-celebrity" (Fisher: 164)) of his own when an intern made him the subject of a MoMA blog entry (Kaganskiy 2010) and journalists followed suit (e.g., Stanley 2010).

To take the photos posted to the Flickr site, Marco Anelli, the show's official photographer, used a telephoto lens and high-speed camera that allowed him to work quickly from the atrium's outer perimeter. The resulting images highlighted the sitters' individual facial features and emphasized their emotional reactions (see fig. 11). For example, when a sitter cried, as many did, Anelli would wait for a tear to run down the subject's face and then record the moment when it caught the light (Anelli 2012: 7). In 2012 Anelli published selected photographs from the exhibit in a book, Portraits in the Presence of Marina Abramović, and appended a note to each indicating the length of time the portrait subject had sat opposite the artist. The book glamorized everyone involved by reproducing the

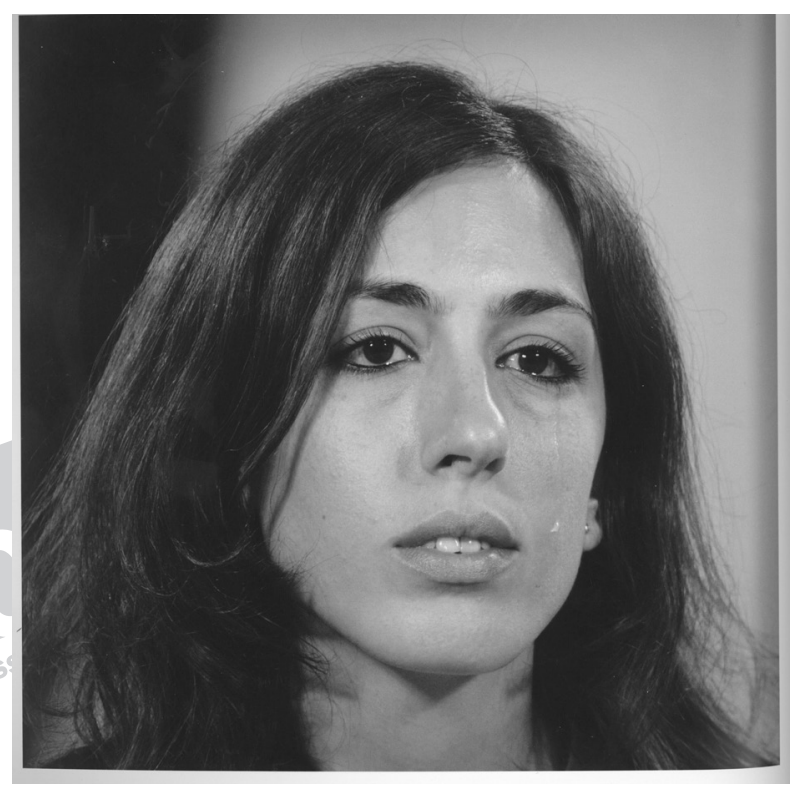
photos at high resolution and on heavy glossy paper. Abramović appears several times in close-ups that occupy an entire nine-by-nine-inch page; selected other sitters fill an entire page or appear four on a page, while far smaller photographs of everyone who sat opposite Abramović appear en masse in yearbook-like format at the back of the book (see figs. 12 and 13). Those selected for enlargement resemble both the winners of a talent contest and the winners of a contest to achieve parity with the artist herself, since her image is almost always the sole occupant of the pages on which it appears.

The show's extension to the Flickr site, a live-streaming channel, and numerous blogs was itself the subject of much commentary in Internet and print media.
Figure 11 Photograph by Marco Anelli ๔ 2010. Courtesy Danziger Gallery. From Portraits in the Presence of Marina Abramović (Anelli 2012) 
|Figure 12 Photograph by Marco Anelli ๔ 2010. Courtesy Danziger Gallery. From Portraits in the Presence of Marina Abramović (Anelli 2012)
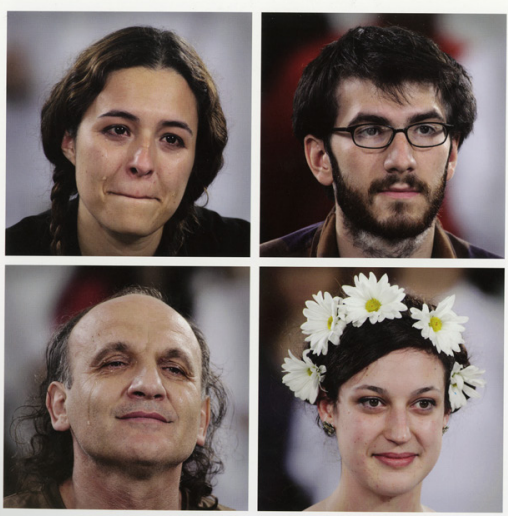

: : : : : 1: 1 :
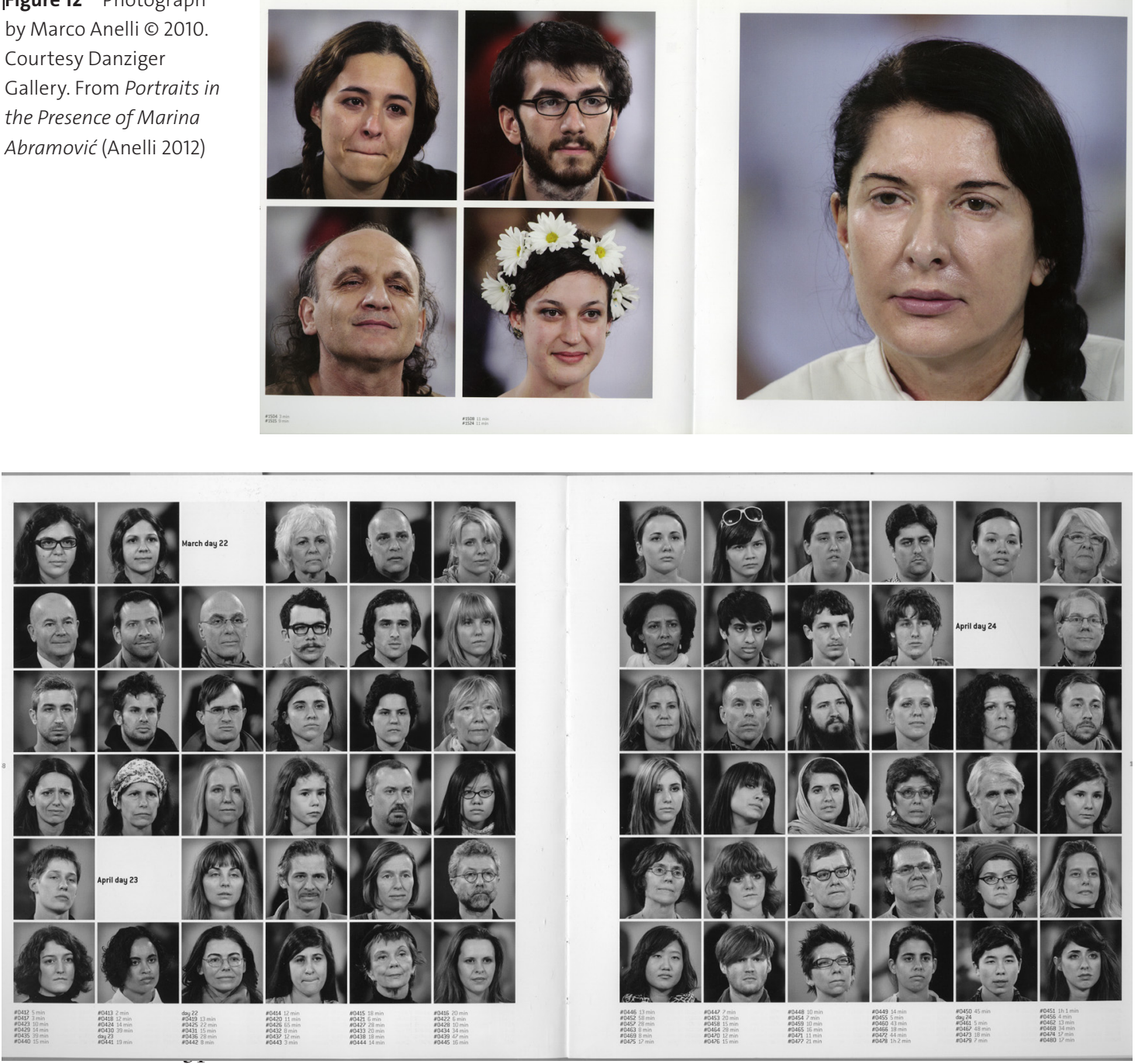

Figure 13 Photograph by Marco Anelli ๔ 2010. Courtesy Danziger Gallery. From Portraits in the Presence of Marina Abramović (Anelli 2012)
Many people blogged about their experience watching the live-streaming video, and the new photos added daily to Flickr became occasions for further digital networking. "The making and viewing of Anelli's portraits was ... a social event. ... The images were quickly copied onto different websites undergoing numerous repetitions, re-groupings and written commentaries by their online viewing public. The portraits [had] wide accessibility across the internet, where they were watched like television and consulted like an archive" (Iles 2012: 19-20; see also 

“@marinaschair" inserted the show into a daily news cycle that compounded people's curiosity about who had sat opposite the artist each day, which in turn fed people's desire to be seen having done so.

Though there is no evidence that Abramović had Twitter or Facebook in mind when she conceived of "The Artist Is Present," the show took place at a moment when social media usage was rapidly increasing and had begun to coalesce around a small number of platforms. Twitter attained 18.2 million users in May 2009; by January 2010 that number had increased to 27.2 million (Marwick and boyd 2011: 142), and by April 2010 the company announced that it had 105,779,710 users and was growing at a rate of 300,000 users per day (see Huffington Post 2010). By 2010 Facebook had already experienced a stupendous growth spurt and become a significant publicity tool. Obama's 2008 campaign used Facebook to reach unprecedented numbers of people, and in 2009 Lady Gaga's team changed the tenor of her Facebook posts from impersonal items about concert dates to posts in which Lady Gaga directly addressed her "little monsters," who numbered over 10 million on Facebook by July 2010.

In some obvious ways, "The Artist Is Present" defined itself against the Internet: at a moment when virtual contact was expanding, the show exalted live presence; in an age of web surfing, it challenged participants to help the artist sustain an oasis of concentration. Even in this regard, however, the performance and its online documentation resembled Internet metrics that measure how many people and how long they look at a site, with their frequently updated tabulation of visitors, sitters, and amount of time sat. Like other new media and genres before it (print, novels, film, television, comic books, video games), the Internet has been accused of launching an age of distraction, but it would be more accurate to say that it has created a new economy of attention (see Marwick, in this issue; Grindstaff and Murray, in this issue). Celebrities depend more than ever before on the time and interest that their fans and voluntary public bestow on them, and that time and interest have become newly visible and quantifiable. By incorporating the audience into Abramović's performance and regularly recording its mounting attention levels, "The Artist Is Present" and its online representations made her appeal to viewers as visible and quantifiable as the number of likes on a Facebook page or retweets on Twitter.

In addition to making its attention metrics an object of attention in their own right, "The Artist Is Present" highlighted the interactivity characteristic of social media, which has led to the formation of what some have called Celebrity 2.0, referring to the ways that artists now incorporate contact with audiences into their 
art itself (Lawson 2009). Interactions between fans and celebrities have become not only more numerous and visible but also more reciprocal, though not perfectly so. As a result, celebrities now engage more frequently in acts that recognize and acknowledge their fans. In the past, celebrity discourse highlighted fans enthusing about celebrities; now the most popular celebrities regularly manifest their adoration for their fans. Consider Lady Gaga's July 21, 2009, Facebook post: "A poem for my fans: 'in every minute of the day, the truth is that I'm dead, until I'm here on stage, with you, then I'm alive instead.' "That post elicited almost nineteen hundred comments in two days, just one illustration among many that celebrity discourse no longer consists primarily of messages broadcast by celebrities and their industries but now also consists of fans' rapidly incorporated, highly visible responses to those messages.

When celebrities and other fans favorite, like, share, retweet, reply at, or comment on a fan's comments, they rapidly broadcast the actions of that individual fan to all of the celebrity's fans. As a result, fans like Blancas now have names and faces that are nearly as visible to other fans as the names and faces of celebrities themselves. Like older media and communication networks - the postal service, commercial photography, and telegraph cable news-social media services give the impression of increased access to celebrities. Unlike older media, they also afford individual fans much greater access to other fans. By promoting multidirectional communication, social media offer fans more opportunities to be recognized by celebrities and enable fans to recognize one another being looked at by a celebrity —or being ignored by one. When Abramović placed sitters in a chair identical to hers and asked them to engage in the same act of sustained looking as she did, she conferred the recognition of her gaze, but her decision never to respond to her sitters' most outlandish provocations with anything more than an unflinching stare also withheld her recognition.

The ways that Abramović's show put a multitude of individual interactions between a celebrity and her fans on display for a larger public helps us understand why social media seem to have amplified celebrity culture. In the classical celebrity culture generated by theater, print, and broadcast media, fans tended to manifest publicly as a crowd or mass, attending or tuning in to the same events on the same nights, applauding as one when performances ended. With Twitter and Facebook, as with "The Artist Is Present," it is as though, instead of the entire audience applauding together briefly after a performance ends, each individual audience member has the opportunity to applaud solo, as part of a sustained serial ovation that has itself become part of the content of the performance. Most theater 

the Abramović show, normalize the anomalous position of the heckler, affectionate or otherwise, and return audiences to the engaged, active stance that characterized them before 1850 (Johnson 1996; L. Levine 1990; Maslan 2005; Cavicchi 2011). In the past, however, most actors had to master the art of ignoring or overcoming rowdy audiences. On social media, celebrities reward fans' attention with the coin of attention itself, which they can now even dole out to fans one by one, in full view of other fans and their voluntary public.

\section{Conclusion}

What can we conclude, then, about how the Internet era has changed celebrities and their publics, and what can the case of Marina Abramović teach us about the larger implications of those changes? The most significant feature of social media with respect to celebrity is their capacity for multidirectional dialogues that can feel private but are in fact public. Social media increase the speed, ease, and visibility of celebrity-fan interactions and make it easier for fans to address celebrities, celebrities to address fans, and fans to address one another. By making these interactions visible to all the members of a celebrity's public, voluntary and involuntary, social media allow fans to draw attention to themselves in the act of paying attention to celebrities.

Social media also enable more people to engage in celebrity practices such as displaying privacy in public and vaunting distinctive personality traits. Some scholars have therefore argued that social networking services and participatory digital media have narrowed the gap and blurred the line between celebrities and fans (Marshall 2006: 640), creating opportunities for microcelebrity (Senft 2013). ${ }^{8}$ Others correctly point out, however, that practicing celebrity does not itself confer celebrity status (Marwick and boyd 2011: 141) and that a small number of figures continue to monopolize media coverage (Van de Rijt et al. 2013). Indeed, by promoting interactions that draw more people to give more time and attention to celebrities, social media provide celebrities with more ways to extract time and money from fans and voluntary publics and more ways to increase their involuntary publics communities, but that phenomenon remains the exception rather than the rule. It tends to obtain among smaller fan publics or ones organized around popular fiction and fictional characters, rather than living celebrities. See Senft 2013: 350. 
by blurring personal and commercial circuits. Similarly, Abramović provided many sitters with a unique and moving experience and gave each of them an individual place in MoMA's archive, but whether taken individually or collectively, those sitters bestowed far more celebrity and resources on her than they themselves received.

Researchers often announce with great fanfare that they have proved that celebrity is not becoming more inclusive and democratic (e.g., Page 2012; Van de Rijt et al. 2013), but we should not be surprised that social media have not radically democratized celebrity culture. Given that inequality is the essence of celebrity, such a finding is to be expected. Being granted equal access to the same media platforms as celebrities, or even to the same audiences, does not translate into equal shares of the attention they command. Because celebrity is defined by the quantitative difference between the numbers of people giving and receiving attention, a world in which everyone received equal attention would be a world without celebrity. Celebrity is an exclusive status reserved for a very few people, a status that many people imagine they would like to possess but know they won't obtain, a club fewer people would want to enter if everyone could be a member. Celebrities fascinate us because superiority and privilege fascinate us. But celebrity also attracts us because we value democracy and populism, and celebrity is a privilege that only publics can grant; celebrities are a democratically legitimated elite (Turner 2004: 117; Gamson 1994: 132). In worshipping celebrities we worship both our own powers and our persistent powerlessness. As a privileged status that members of a public confer on others but that individuals cannot award to themselves, celebrity is democratic and elitist (Rojek 2001: 146, 179), ineluctably social and persistently individualistic.

By giving their time, money, energy, votes, attention, and engagement, fans and voluntary publics create the celebrities who impose themselves on involuntary publics. Fans crave to have a portion of the recognition they offer returned to them by celebrities and by other fans, and the rise of social media has made it easier to compete for those often infinitesimal doses of acknowledgment. "The Artist Is Present" turned the dynamics of celebrity itself into art. In a sense, Abramović's performance was a metacelebrity event that made its creator a celebrity because it was itself about celebrity. For some, the connections between "The Artist Is Present" and celebrity culture signaled the death of performance art, but the show's real significance may lie in its artful grasp of the ongoing life of celebrities and their publics as new media come to supplement the old. 
Abramović, Marina. 2010a. "Artist Marina Abramovic Sits for an Interview.” By Rachel Dodes. Speakeasy (blog), Wall Street Journal, June 1. blogs.wsj.com /speakeasy/2010/06/01/artist-marina-abramovic-sits-for-an-interview. and Zoë Jackson. Inside/Out: A MoMA/MoMA PS1 Blog, June 3. www.moma .org/explore/inside_out/2010/06/03/marina-abramovic-the-artist-speaks.

— 2011. "The Artist Is Present: Marina Abramovic Interviewed by Iwona Blazwick." Art Monthly, September. web.a.ebscohost.com.ezproxy.cul.columbia .edu/ehost/detail?vid=3\&sid=222252ce-a3ef-4840-8e 59-48043f99fdd4\% 40 sessionmgr4004\&hid=4112\&bdata $=$ JnNpdGU9ZWhvc3QtbG12ZSZzY29 wZT1zaXRl\#db=asu\&AN=527669610

—. 2013. “Life and Art: Marina Abramović, Interview.” By Eugenio Viola. Dust Magazine, no. 4 (n.p.).

Adorno, Theodor W. 2001. The Culture Industry: Selected Essays on Mass Culture. Routledge Classics. New York: Routledge.

Affron, Charles. 1977. Star Acting: Gish, Garbo, Davis. New York: Dutton.

Anelli, Marco. 2012. Portraits in the Presence of Marina Abramović. Selected photographs from "The Artist Is Present," performed at the Museum of Modern Art (New York), 2010. Bologna, Italy: Damiani.

Biesenbach, Klaus, ed. 2010a. Marina Abramović: The Artist Is Present. New York: Museum of Modern Art.

- 2010b. "Marina Abramović: The Artist Is Present. The Artist Was Present. The Artist Will Be Present." In Biesenbach, Marina Abramović, 12-21.

Boorstin, Daniel J. 2006. "From Hero to Celebrity: The Human Pseudo-Event." In The Celebrity Culture Reader, edited by P. David Marshall, 72-90. New York: Routledge.

Braudy, Leo. 1997 [1986]. The Frenzy of Renown: Fame and Its History. New York: Vintage Books.

Cavicchi, Daniel. 2011. Listening and Longing: Music Lovers in the Age of Barnum. Middletown, CT: Wesleyan University Press.

Chen, Adrian. 2010. "Vomit! Nudity! Litter! Marina Abramovic's Marathon Performance Ends in Chaos." Gawker, May 31. gawker.com/5551849/vomit -nudity-litter-marina-abramovics-marathon-performance-piece-ends-in-chaos.

Dames, Nicholas. 2001. "Brushes with Fame: Thackeray and the Work of Celebrity." Nineteenth-Century Literature 56, no. 1: 23-51. doi:10.1525/ncl .2001.56.1.23. 
Danto, Arthur. 2010. "Danger and Disturbation: The Art of Marina Abramović." In Biesenbach, Marina Abramović, 28-35.

Debord, Guy. 1977. The Society of the Spectacle. Detroit: Black and Red.

Dyer, Richard. 1979. Stars. London: BFI.

Ferris, Kerry. 2011. Stargazing: Celebrity, Fame, and Social Interaction. New York: Routledge.

Fisher, Jennifer. 2012. "Proprioceptive Friction: Waiting in Line to Sit with Marina Abramovic." Senses and Society 7, no. 2: 153-72.

Gamson, Joshua. 1994. Claims to Fame: Celebrity in Contemporary America. Berkeley: University of California Press.

Garvey, Ellen Gruber. 2012. Writing with Scissors: American Scrapbooks from the Civil War to the Harlem Renaissance. New York: Oxford University Press. Grobe, Christopher. 2011. "Twice Real: Marina Abramović and the Performance Archive." Theater 41, no. 1: 104-13. doi:10.1215/01610775-2010-025.

Hamera, Judith. 2012. "The Labors of Michael Jackson: Virtuosity, Deindustrialization, and Dancing Work." PMLA 127, no. 4: 751-65. doi:10.1632/pmla .2012.127.4.751.

Hinerman, Stephen. 2006. “(Don't) Leave Me Alone: Tabloid Narrative and the Michael Jackson Child-Abuse Scandal." In Marshall, Celebrity Culture Reader, 454-69.

Hirschorn, Michael. 2013. "Why Pop Stars Rule the World and Movie Stars Hardly Matter." Vulture, May 25. www.vulture.com/2013/05/why-pop-stars-rule-the -world.html.

Holmes, Su, and Sean Redmond, eds. 2006. Framing Celebrity: New Directions in Celebrity Culture. New York: Routledge.

Huffington Post. 2010. "Twitter User Statistics Reveal." April 4. www.huffington post.com/2010/04/14/twitter-user-statistics-r_n_537992.html.

Iles, Chrissie. 2012. "Marco Anelli: Portraits in the Presence of Marina Abramović." In Anelli, Portraits, 13-21.

Jenkins, Henry. 2006. Fans, Bloggers, and Gamers: Exploring Participatory Culture. New York: New York University Press.

Jenkins, Henry, Sam Ford, and Joshua Green. 2013. Spreadable Media: Creating Value and Meaning in a Networked Culture. New York: New York University Press.

Johnson, James H. 1996. Listening in Paris: A Cultural History. Berkeley: University of California Press. 
Jones, Amelia. 2011. “The Artist Is Present': Artistic Re-enactments and the Impossibility of Presence." TDR: The Drama Review 55, no. 1: 16-45. doi:10.1162/DRAM_a_00046.

Kaganskiy, Julia. 2010. "Visitor Viewpoint: MoMA's Mystery Man.” Inside/Out: A MoMA/MoMA PS1 Blog, May 10. www.moma.org/explore/inside_out/2010 /05/10/visitor-viewpoint-momas-mystery-man/.

Kemp, Martin. 2012. Christ to Coke: How Image Becomes Icon. New York: Oxford University Press.

Kurzman, Charles, et al. 2007. "Celebrity Status." Sociological Theory 25, no. 4: 347-67. doi:10.1111/j.1467-9558.2007.00313.x.

Lady Gaga's Facebook page. July 21, 2009. www.facebook.com/ladygaga.

Lambert-Beatty, Carrie. 2009. "Against Performance Art." Artforum International 48, no. 9: 208-12.

Langer, John. 2006. “Television's 'Personality System.'” In Marshall, Celebrity Culture Reader, 181-95.

Lawson, Steve. 2009. "Celebrity 2.0-Fame in a Conversation-Economy." Stevelawson.net, March 1. www.stevelawson.net/2009/03/celebrity-20-fame-in -a-conversation-economy.

Levine, Abigail. 2010. "Marina Abramović's Time: The Artist Is Present at the Museum of Modern Art." E-Misférica, 7, no. 2. hemisphericinstitute.org/hemi/en le-misferica-72/levine.

Levine, Lawrence W. 1990. Highbrow, Lowbrow: The Emergence of Cultural Hierarchy in America. Cambridge, MA: Harvard University Press.

Life. 1879. "The True Story of Sarah-Bernhardt." July 12.

Lowenthal, Leo. 1968. Literature, Popular Culture, and Society. Palo Alto, CA: Pacific Books.

Lyall, Sarah. 2013. "For Her Next Piece, a Performance Artist Will Build an Institute." New York Times, October 10.

MAI (Marina Abramović Institute). 2013a. “The Abramovic Method Practiced by Lady Gaga." Vimeo, vimeo.com/71919803.

—. 2013b. "Marina Abramovic Institute: The Founders." Kickstarter, www .kickstarter.com/projects/maihudson/marina-abramovic-institute-the-founders.

Marcus, Sharon. 2011. "Salomé!! Sarah Bernhardt, Oscar Wilde, and the Drama of Celebrity.” PMLA 126, no. 4: 999-1021. doi:10.1632/pmla.2011.126.4.999.

Marshall, P. David. 1997. Celebrity and Power: Fame in Contemporary Culture. Minneapolis: University of Minnesota Press. 
2006. "New Media—New Self: The Changing Power of Celebrity." In Marshall, Celebrity Culture Reader, 634-44.

Marwick, Alice E., and danah boyd. 2011. "To See and Be Seen: Celebrity Practice on Twitter." Convergence: The International Journal of Research into New Media Technologies 17, no. 2: 139-58. doi:10.1177/1354856510394539.

Maslan, Susan. 2005. Revolutionary Acts: Theater, Democracy, and the French Revolution. Baltimore: Johns Hopkins University Press.

Mills, C. Wright. 1999 [1956]. The Power Elite. New York: Oxford University Press.

Milner, Murray. 2010. "Is Celebrity a New Kind of Status System?" Society 47, no. 5: 379-87. doi:10.1007/s12115-010-9347-x.

MoMA (Museum of Modern Art). 2010. "Marina Abramovic: Live at MoMA." YouTube video, 2:15. MoMAvideos, uploaded March 31. www.youtube.com /watch?v=2GD5PBK_Bto.

Morin, Edgar. 1957. Les stars. Paris: Seuil.

Murray, Susan. 2005. Hitch Your Antenna to the Stars: Early Television and Broadcast Stardom. New York: Routledge.

Nussbaum, Felicity. 2010. Rival Queens: Actresses, Performance, and the EighteenthCentury British Theater. Philadelphia: University of Pennsylvania Press.

O'Hagan, Sean. 2010. "Interview: Marina Abramović." Guardian, October 2. www .theguardian.com/artanddesign/2010/oct/03/interview-marina-abramovic -performance-artist.

Page, Ruth. 2012. "The Linguistics of Self-Branding and Micro-Celebrity in Twitter: The Role of Hashtags." Discourse and Communication 6, no. 2: 181-201. doi:10.1177/1750481312437441.

Palmer, David L. 1998. "Virtuosity as Rhetoric: Agency and Transformation in Paganini's Mastery of the Violin." Quarterly Journal of Speech 84, no. 3: 341-57. doi:10.1080/00335639809384223.

Phelan, Peggy. 1993. Unmarked: The Politics of Performance. London, New York: Routledge.

Phelan, Peggy. 2004. "Marina Abramovic: Witnessing Shadows." Theatre Journal 56, no. 4: 569-77.

Polan, Dana. 2011. Julia Child's “The French Chef." Durham, NC: Duke University Press.

Punathambekar, Aswin. 2008. “'We're Online, Not on the Streets': Indian Cinema, New Media, and Participatory Culture." In Global Bollywood, edited by Anandam P. Kavoori and Aswin Punathambekar, 282-99. New York: New York University Press. 
restoredfaithih. 2013. "Marina Abramovic_Ulay Visits 'The Artist Is Present.", YouTube video, 3.36. March 10. www.youtube.com/watch?v=R4lp4w81NYs. Roach, Joseph. 2007. It. Ann Arbor: University of Michigan Press.

Rojek, Chris. 2001. Celebrity. London: Reaktion Books. .com/magazineus/features/saltz/marina-abramovic-it-was-all-about-you6-1-10 .asp.

—. 2013. “ “Picasso Baby’ Live: Jerry Saltz Goes Face-to-Face with Jay-Z for Six Hours." New York Magazine, July 10.

Schickel, Richard. 1985. Intimate Strangers: The Culture of Celebrity in America. Garden City, NY: Doubleday.

Schmid, David. 2006. Natural Born Celebrities: Serial Killers in American Culture. Chicago: University of Chicago Press.

Schor, Mira. 2010. "Looking for Art to Love, MoMA: A Tale of Two Egos." A Year of Positive Thinking, May 8. ayearofpositivethinking.com/2010/05/08 /looking-for-art-to-love-moma-a-tale-of-two-egos.

Senft, Theresa M. 2013. "Microcelebrity and the Branded Self." In Hartley, Burgess, and Bruns, Companion to New Media Dynamics, 346-54.

Siegel, Miranda. 2010. "Water Definitely Not Included." New York Magazine, May 23. nymag.com/arts/art/features/66163.

Smart, Barry. 2005. The Sport Star: Modern Sport and the Cultural Economy of Sporting Celebrity. Thousand Oaks, CA: Sage.

Stacey, Jackie. 1994. Star Gazing: Hollywood Cinema and Female Spectatorship. New York: Routledge.

Stanley, Caroline. 2010. "Meet the Man Who Sat with Marina Abramović Fourteen Times." Flavorwire, May 10.flavorwire.com/89459/meet-the-man-who-sat-with -marina-abramovic-14-times.

Stern, Michael. 2010. "The Face as a Fingerprint: Mediation, Silence, and the Question of Identity in Ingmar Bergman's Persona." Konturen 3. journals .oregondigital.org/konturen/article/view/1421/1591.

Tuite, Clara. 2007. "Tainted Love and Romantic Literary Celebrity." ELH 74, no. 1: 59-88. doi:10.1353/elh.2007.0009.

Turner, Graeme. 2004. Understanding Celebrity. Thousand Oaks, CA: Sage.

Van de Rijt, Arnout, et al. 2013. "Only Fifteen Minutes? The Social Stratification of Fame in Printed Media.” American Sociological Review 78, no. 2: 266-89. doi:10.1177/0003122413480362.

Vartanian, Hrag. 2010. "MoMA's Abramović Ends with a Bang." Hyperallergic, June 1. hyperallergic.com/6611/moma-abramovic-line-ends. 
Public Culture 1 (2) 3
Yablonsky, Linda. 2010. "Marina the Magnificent." T Magazine (blog), New York Times, June 2. tmagazine.blogs.nytimes.com/2010/06/02/artifacts-marina-the -magnificent.

Yates, Edmund. 1877-79. Celebrities at Home. 3 vols. London: Office of "The World."

Sharon Marcus is Orlando Harriman Professor of English and Comparative Literature and dean of humanities at Columbia University. She is the author of Apartment Stories: City and Home in Nineteenth-Century Paris and London (1999) and of the prize-winning Between Women: Friendship, Desire, and Marriage in Victorian England (2007). She is currently completing a book on theatrical celebrity in the nineteenth century. 